\title{
PENGARUH PROKRASTINASI AKADEMIK TERHADAP HASIL BELAJAR BIOLOGI SISWA SMA NEGERI DI KOTA MAKASSAR
}

\author{
Anisa \\ Universitas Muhammadiyah Makassar, anisa@unismuh.ac.id \\ Ernawati \\ Universitas Muhammadiyah Makassar, ernawati@unismuh.ac.id
}

\begin{abstract}
Abstrak
Penelitian ini bertujuan menganalisis pengaruh prokrastinasi akademik terhadap hasil belajar Biologi siswa SMA Negeri di Kota Makassar. Penelitian ini berjenis ex-post facto. Populasi penelitian ini adalah seluruh siswa SMA Negeri di Kota Makassar tahun ajaran 2017/2018. Sampel penelitian sebanyak 335 siswa, diperoleh dengan menggunakan teknik random sampling. Variabel yang diteliti adalah: (1) variabel bebas adalah prokrastinasi akademik dengan simbol X; (2) variabel terikat adalah hasil belajar dengan simbol Y. Teknik pengumpulan data dengan menggunakan angket untuk memperoleh skor prokrastinasi akademik, sedangkan hasil belajar siswa diperoleh dari dokumentasi nilai hasil belajar biologi tahun akademik 2017/2018 siswa pada SMA Negeri 1 Makassar. Hasil penelitian menunjukkan; pengaruh prokastinasi akademik terhadap hasil belajar siswa SMA Negeri di Kota Makassar berada pada kategori sedang.
\end{abstract}

Kata Kunci: prokrastinasi akademik, hasil belajar

\begin{abstract}
This research aims to find out the influence of academic procrastination to the student achievements in biology at SMAN in Makassar. This research was ex-post facto. The population in this research were all students of SMA Makassar in the academic year 2017/2018. Samples are obtained with 335 students random sampling technique. The variables studied were : (1) the independent variable is academic procrastination with symbols $X$; and ( 2 ) the dependent variable is the student achievements in biology with the symbol Y. Data collecting technique by using a questionnaire to obtain scores of academic procrastination whereas the student achievements in biology obtained from the study of biological documentation of the value of the study of biology semester academic year 2017/2018 at SMAN 1 Makassar. The results obtained show that the influence of academic procrastination to the student achievements in biology at SMAN in Makassar was in medium category.
\end{abstract}

Keywords: academic procrastination, student achievements 


\section{PENDAHULUAN}

Upaya peningkatan mutu pendidikan guna membentuk generasi penerus bangsa yang berkarakter dan berdaya saing tinggi di berbagai bidang tidak henti dilakukan. Semua itu bertujuan untuk menghadapi era persaingan bebas dengan berbagai bangsa dan negara. Untuk menghadapi persaingan tersebut para generasi muda di antaranya para pelajar/ siswa yang sedang mengenyam bangku sekolah, harus dibekali dengan ilmu pengetahuan dan teknologi yang memadai. Tidak hanya itu, mereka juga harus dibekali dengan sikap bekerja keras dan pantang menyerah serta kedisiplinan yang tinggi.

Peningkatan mutu pendidikan ini tentunya harus didukung oleh hasil belajar siswa yang tinggi. Namun, untuk mencapai hasil belajar yang maksimal, tentunya mengalami banyak kendala dan hambatan. Banyak faktor yang mempengaruhinya baik secara eksternal maupun internal. Salah satu faktor internal yang adalah kebiasaan menunda tugas ataupun pekerjaan yang dilakukan oleh siswa.

Kebiasaan menunda-menunda tugas tersebut biasa disebut prokrastinasi, karena tugasnya merupakan bagian dari aktivitas akademik, maka dapat disebut prokrastinasi akademik. Prokrastinasi dapat terjadi karena berbagai factor antara lain tidak menyukai tugas yang diberikan, takut gagal dalam menyelesaikan tugas, dan tak jarang mereka melakukan aktivitas lain yang lebih menarik dibanding menyelesaikan tugas mereka.

Kebiasaan menunda-nunda tugas ini tidak menutup kemungkinan akan berpengaruh terhadap prestasi atau hasil belajar mereka di sekolah. Seperti penelitian yang dilakukan oleh Ramadhan (2016), mereka melakukan penelitian di salah satu SMK swasta di Bandung, dari hasil penelitian mereka menunjukkan terdapat pengaruh negatif dan signifikan variabel prokrastinasi akademik terhadap prestasi belajar siswa dan tingkat prokrastinasi yang dilakukan oleh siswa hampir berada pada kategori tinggi. Hal yang serupa dilakukan oleh Burhan dkk, (2017) meneliti tentang motivasi dan prokrastinasi terhadap hasil belajar siswa menyimpikan bahwa terdapat hubungan positif yang signifikan antara motivasi intrinsik dan prokrastinasi akademik dengan hasil belajar pengurus HMJ Pendidikan Biologi Universitas Islam Negeri Alauddin Makassar.

Tujuan penelitian ini adalah menganalisis pengaruh prokrastinasi akademik terhadap hasil belajar Biologi siswa SMA Negeri di Kota Makassar 


\section{METODOLOGI PENELITIAN}

Penelitian berjenis ex-post facto yang bersifat "korelasional" karena diselidiki hubungan antara variabel. Penelitian dilaksanakan di SMA Negeri 1 Makassar. Populasi penelitian ini adalah seluruh siswa SMA Negeri di Kota Makassar yang berjumlah 768 siswa. Sampel penelitian sebanyak 335 siswa, diperoleh dengan menggunakan teknik random sampling. Variabel yang diteliti adalah: (1) variabel bebas adalah prokrastinasi akademik; (2) variabel terikat adalah hasil belajar. Teknik pengumpulan data dengan menggunakan angket untuk memperoleh tingkat prokrastinasi akdemik siswa, sedangkan hasil belajar mahasiswa diperoleh dari dokumentasi nilai hasil belajar biologi siswa tahun akademik 2017/2018. Data yang diperoleh kemudian dianalisis secara kuantitatif dengan menggunakan teknik statistik, secara statistik deskriptif dan inferensial.

\section{HASIL DAN PEMBAHASAN}

\section{Prokrastinasi Akademik}

Data prokrastinasi akademik siswa SMA Negeri di Kota Makassar tersaji pada Tabel 1. Pada tabel, dapat dilihat bahwa prokastinasi akademik siswa berada pada kategori tinggi dengan presentase $32.84 \%$.

Tabel 1 Distribusi Frekuensi dan Persentase Prokrastinasi Akademik Siswa SMA Negeri di Kota Makassar

\begin{tabular}{llll}
\hline Kategori & Nilai skor & Frekuensi & Persentase (\%) \\
\hline Sangat tinggi & $\geq 78$ & 22 & 6.57 \\
Tinggi & $67-77$ & 110 & 32.84 \\
Sedang & $57-66$ & 100 & 29.85 \\
Rendah & $47-56$ & 83 & 24.78 \\
Sangat rendah & $\leq 46$ & 20 & 5.96 \\
\hline Jumlah & & 335 & 100 \\
\hline
\end{tabular}

\section{Hasil Belajar}

Data hasil belajar siswa SMA Negeri di Kota Makassar tersaji pada Tabel 1. Pada tabel, dapat dilihat bahwa hasil belajar siswa SMA Negeri di Kota Makassar berada pada kategori tinggi dengan presentase $32.24 \%$. 
Tabel 2 Distribusi Frekuensi dan Persentase Hasil Belajar Siswa SMA Negeri di Kota Makassar

\begin{tabular}{llll}
\hline Kategori & Nilai skor & $\begin{array}{l}\text { Frekuens } \\
\text { i }\end{array}$ & Persentase (\%) \\
\hline Sangat tinggi & $\geq 88$ & 26 & 7.77 \\
Tinggi & $78-87$ & 108 & 32.24 \\
Sedang & $68-77$ & 104 & 31.04 \\
Rendah & $58-67$ & 79 & 23.58 \\
Sangat rendah & $\leq 57$ & 17 & 5.37 \\
\hline Jumlah & & 335 & 100 \\
\hline
\end{tabular}

\section{Uji Hipotesis}

Pengaruh prokrastinasi akademik terhadap hasil belajar; hasil regresi yang telah dilakukan adalah koefisien regresi "b" sebesar 107.394 dengan konstanta "a" sebesar 0.543. Persamaan garis regresi adalah $\hat{Y}=107.394-0.543 \mathrm{X}_{1}$.

Persamaan garis regresi tersebut menunjukkan bahwa setiap kenaikan satu skor prokrastinasi akademik akan menyebabkan penurunan hasil belajar 0.543 pada konstanta 107.394.

Tabel 3 Koefisien Prokrastinasi Akademik (X)

\begin{tabular}{lllll}
\hline $\begin{array}{l}\text { Sumber } \\
\text { Variasi }\end{array}$ & Koefisien & $\begin{array}{l}\text { Standar } \\
\text { Kesalahan } \\
\text { Koefisien }\end{array}$ & t Hitung & Probabilitas \\
\hline Konstanta & 107.394 & 2.574 & 41.727 & 0.000 \\
Kecerdasan Emosional $\left(\mathrm{X}_{1}\right)$ & -0.543 & 0.41 & 13.344 & 0.000 \\
\hline
\end{tabular}

Sumber: Hasil analisis regresi 
Tabel 4 Anova Hubungan Prokrastinasi Akademik $\left(\mathrm{X}_{1}\right)$ dengan Hasil Belajar Biologi (Y) Siswa SMA Negeri di Kota Makassar

\begin{tabular}{llllll}
\hline $\begin{array}{l}\text { Sumber } \\
\text { Variasi }\end{array}$ & $\begin{array}{l}\text { Jumlah } \\
\text { kuadrat }(\mathrm{JK})\end{array}$ & $\begin{array}{l}\text { Derajat } \\
\text { bebas }\end{array}$ & $\begin{array}{l}\text { Rerata kuadrat } \\
(\mathrm{RK})\end{array}$ & $\mathrm{F}_{\text {hitung }}$ & $\begin{array}{l}\mathrm{F}_{\text {tabel }} \\
(\alpha=\end{array}$ \\
\hline Regresi & 10923.331 & 1 & 10923.331 & 178.060 & $3,04)$ \\
Kesalahan & 20305.588 & 332 & 61.346 & & \\
Total & 31228.919 & 332 & & & \\
\hline
\end{tabular}

Tabel di atas menunjukkkan bahwa nilai $\mathrm{F}$ hitung $=178.060$ lebih besar dibandingkan dengan $\mathrm{F}$ tabel pada $\alpha=0,05$ yaitu 3.044. Hal ini menunjukkan bahwa persamaan regresi signifikan.

Analisis korelasi sederhana yang dilakukan untuk menunjukkan seberapa kuat hubungan antara prokrastinasi akademik dengan hasil belajar

Tabel 5 Uji Signifikan Koefisien Korelasi $\mathrm{r}_{\mathrm{y} 1}$

\begin{tabular}{|c|c|c|c|c|c|}
\hline \multirow{2}{*}{$\begin{array}{l}\text { Cacah } \\
\text { Observasi } \\
\text { (df) }\end{array}$} & \multirow{2}{*}{$\begin{array}{l}\text { Koefisien } \\
\text { Korelasi }\end{array}$} & \multirow{2}{*}{$\begin{array}{l}\text { Koefisien } \\
\text { Determinasi }\end{array}$} & \multirow{2}{*}{ t Hitung } & \multicolumn{2}{|l|}{$\mathrm{t}$ Tabel } \\
\hline & & & & $\alpha=0.05$ & $\alpha=0.01$ \\
\hline 334 & 0.591 & 0.350 & 13.334 & 1,65 & 2,33 \\
\hline
\end{tabular}

Hasil analisis regresi linear sederhana menunjukkan bahwa terdapat hubungan antara prokrastinasi akademik dengan hasil belajar biologi siswa SMA Negeri di Kota Makassar. Disimpulkan bahwa jika siswa dengan tingkat prokrastinasi akademik yang tinggi maka hasil belajar biologi siswa SMA Negeri di Kota Makassar rendah maka dalam penelitian ini menolak $\mathrm{H}_{\mathrm{o}}$ dan menerima $\mathrm{H}_{1}$.

Hasil penelitian menunjukkan bahwa tingkat prokrastinasi akademik siswa SMA Negeri di Kota Makassar terbilang tinggi, yaitu sebesar 32.84\%. setelah dilakukan analisis inferensial untuk menguji bagaimana pengaruh prokrastinasi akademik terhadap hasil belajar, hasil regresi yang diperoleh adalah 0.591. Merujuk pada nilai $r$ yang dikemukakan oleh Arikunto (2005), bahwa nilai $r$ tersebut berada pada kategori sedang. Prokrastinasi akademik berkontribusi negatif terhadap hasil belajar sebesar $35 \%$.

Prokrastinasi akademik merupakan penundaan pengerjaan tugas yang dilakukan oleh seseorang. Menurut Ghufron dan Risnawati (2010), prokrastinasi dilakukan secara berulang kali karena kegiatan lain yang tidak berkaitan dengan tugas yang harus dikerjakan. Biasanya siswa akan melakukan aktivitas-aktivitas lain yang menurutnya dianggap lebih menarik dibandingkan mengerjakan tugas, misalnya bermain game, 
melakukan kegiatan ekstrakurikuler di sekolah, menonton film dan lain sebagainya. Saat tiba waktunya untuk mengerjakan tugas, biasanya siswa telah mengalami kelelahan fisik atau pun kehabisan waktu untuk menyelesaikan tugas tersebut.

Penundaan yang dilakukan secara berulang tentu akan mempengaruhi hasil belajar siswa. Kurangnya waktu dalam mengerjakan tugas tentunya akan menyebabkan tugas yang dikerjakan tidak akan mencapai hasil yang maksimal. Keterlambatan pengumpulan tugas dan tugas yang tidak dikerjakan secara maksimal tentunya akan mengurangi penilaian yang dilakukan oleh guru. Siswa yang mengerjakan tugas secara buru-buru atau hanya sekedar melihat tugas yang dibuat oleh teman kelasnya, biasanya tidak terlalu memahami isi dan makna yang terkandung dalam tugas tersebut.

Menurut Ghufron dan Risnawati (2010), keberadaan faktor internal yang telah disebutkan di atas dalam diri siswa yang telah disebutkan di atas, memiliki peranan penting terhadap prokrastinasi yang dilakukan oleh siswa. Misalnya siswa yang lelah secara fisik cenderung melakukan prokratinasi yang lebih tinggi dibanding dengan siswa yang tidak mengalami kelelahan fisik. Pada siswa yang memiliki kepribadian baik dalam meregulasi dirinya dan memanajemen waktu memiliki kecenderungan yang lebih rendah untuk melakukan prokratinasi dibanding siswa yang tidak memiliki regulasi diri dan manajemen waktu yang baik. Begitu pun dengan motivasi dari dalam diri siswa, siswa yang memiliki motivasi yang rendah cenderung akan melakukan prokrastinasi.

Berdasarkan penelitian yang dilakukan oleh Ilyas (2017) siswa yang melakukan prokrastinasi akademik merasa tidak nyaman dengan lingkungannya di sekolah. Salah satunya adalah ketidaksukaan dengan mata pelajaran tertentu yang ditambah dengan cara guru dalam mengelola kelas dan melaksanakan pembelajaran di kelas. Kurangnya inovasi dan kreatifitas guru dalam mengelola pembelajaran, menyebabkan siswa merasa bosan dan berimbas pada kurang pahamnya siswa akan materi pelajaran serta malas untuk mengerjakan tugas yang diberikan.

Munawaroh (2017) mengatakan bahwa siswa yang melakukan prokrastinasi akan mendapat dampak yang positif jika, mereka menunda tugas agar dapat mengerjakannya lebih baik. Namun, dampak negatif yang dapat dialami siswa adalah kehilangan kesempatan untuk mengembangkan pemahaman mengenai suatu topik dengan baik, merasa malas, dan mengalami Lelah secara fisik. 
Berdasarkan hasil penelitian yang dilakukan oleh Munawaroh (2017) di SMP Muhammadiyah 9 Yogyakarta. Munawaroh merekomendasikan bahwa prokrastinasi akademik dapat direduksi dengan cara menggunakan Konseling Ringkas Berfokus Solusi. Guru dapat berperan sebagai konselor yang dapat membantu siswa untuk menghilangkan pandangan negatifnya dan menemukan solusi untuk membantu siswa lepas dari masalah prokrastinasi akademik yang mereka alami.

\section{SIMPULAN}

Berdasarkan hasil penelitian maka dapat disimpulkan bahwa prokrastinasi akademik berpengaruh pada hasil belajar biologi siswa SMA Negeri di Kota Makassar berada pada kategori sedang.

\section{UCAPAN TERIMA KASIH}

Kami mengucapkan banyak terima kasih kepada berbagai pihak yang terkait dalam penelitian ini, khususnya kepada Direktorat Riset dan Pengabdian Masyarakat Direktorat Jenderal dan Penguatan Riset dan Pengembangan Kementrian Riset, Teknologi, dan Pendidikan Tinggi.

\section{DAFTAR PUSTAKA}

Arikunto, Suharsimi. (2007). Prosedur Penelitian: Suatu Pendekatan Praktek. Jakarta: Rineka Cipta.

Burhan, Suniaty., dkk (2017). Hubungan Antara Motivasi Intrinsik Dan Prokrastinasi Akademik Dengan Hasil Belajar Pengurus Hmj Pendidikan Biologi. Jurnal Biotek. Vol 5 No.2

Ghufron, M.N \& Risnawati R. (2010). Teori-Teori Psikologi. Yogyakarta: Ar-Ruzz Media Group.

Ilyas, Muhammad dan Suryadi. (2017). Perilaku Prokrastinasi Akademik Siswa di SMA Islam Terpadu (IT) Boarding School Abu Bakar Yogyakarta. Jurnal An-Nida' (online), $\quad$ Vol. $41, \quad$ No.1 (ejournal.uinsuska.ac.id/index.php/Anida/article/download/4638/2832, diakses 5 Agustus 2018).

Morissan. (2012). Metode Penelitian Survei. Jakarta: Kencana.

Munawaroh, Martika Laely., Said Alhadi.,\& Wahyu Nanda Eka Saputra. (2017). Tingkat Prokrastinasi Akademik Siswa Sekolah Menengah Pertama Muhammadiyah 9 Yogyakarta. Jurnal Kajian Bimbingan dan Konseling, Vol.2, No.1 (http://journal2.um.ac.id/index.php/jkbk, diakses 5 Agustus 2018).

Ramadhan, Restu Pangestu \& Hendri Winata. (2016). Prokrastinasi Akademik Menurunkan Prestasi Belajar Siswa. Jurnal Pendidikan Manajemen Perkantoran, Vol.1, No.1. (ejournal.upi.edu/index.php/jpmanper, diakses 5 Agurtus 2018). 
Slameto. (2010). Belajar dan Faktor-faktor yang Mempengaruhinya. Jakarta: Rineka Cipta.

Sugiyono. (2010). Metode Penelitian Pendidikan(Pendekatan Kuantitatif, Kualititatif, dan $R \& D)$. Bandung: Alfabeta.

Thoha, Chabib. (2003). Teknik Evaluasi Pendidikan. Jakarta: Raja Grafindo Persada.

Tiro, Muhammad Arif. (2008). Analisis Korelasi dan Regresi. Makassar: State University of Makassar Press. (2008). Dasar-Dasar Statistika. Makassar: Andira Publisher 